\title{
Sosialisasi dalam Mengoptimalkan Roda Bisnis pada Masa Pandemi
}

\author{
Asti Gumartifa ${ }^{1}$, Maftuhah Nurrahmi ${ }^{2}$, Bengawan Alfaresi ${ }^{3}$ \\ ${ }^{1,2}$ Fakultas Ekonomi dan Bisnis, \\ ${ }^{3}$ Fakultas Teknik Elektro, \\ Universitas Muhammadiyah Palembang, Palembang, Indonesia
}

\section{Article history}

Received: 10-02-2021

Revised: 15-02-2021

Accepted: 14-03-2021

*Corresponding Author:

Asti Gumartifa,

Fakultas Ekonomi dan Bisnis, Universitas Muhammadiyah

Palembang, Palembang,

Indonesia;

Email:

asti.gumartifa.ump@gmail.com

Abstract: Indonesia has had a lot of changes that have occurred in society. Especially during the current Covid -19 Pandemic. All activities from the process of school, buying, and selling among the community are often carried out online or work from home. The economic income of the family, community, and government has also decreased. The existence of Internet facilities can greatly assist all people in carrying out economic activities to be able to survive during the pandemic. Even these activities are carried out online or still carried out at home. By utilizing social media that is facilitated by the internet, people can continue to carry out buying and selling activities to maintain economic income through online. Here are social media that can be used, namely; Instagram, Facebook, Whats up, and e-mail. Thus, from the use of social media, it can still help the business income even in the pandemic of Covid -19.

Keywords: internet; technology; media; income; economics

Abtrak: Indonesia memiliki banayak sekali perubahan yang terjadi pada masyarakat. Khusus nya pada masa Pandemi covid -19 saat ini. Segala kegiatan dari proses kegiatan sekolah dan jual beli dikalangan masyarakatpun sering dilaksanakan secara offline atau work from home. Pendapatan ekonomi keluarga, masyarakat, serta pemerintahpun mengalami penurunan. Adanya fasilitas Internet sangatlah dapat membantu semua kalangan masyarakat dalam melaksanakan kegiatan perekonomian tetap atau mampu bertahan selama pandemic yaitu dilaksanakan secara online atau tetap dapat berlangsung dan dilakukan dirumah. Dengan memanfaatkan media social yang difasilitasi oleh internet masyarakat dapat tetap melakukan kegiatan ekonomi melalui online. Berikut adalah media social yang dapat di manfaatkan yaitu; instagram, facebook, whats up, dan e-mail. Sehingga, dari pemanfaatan media social tersebut tetap dapat membantu roda bisnis atau roda perekonomian keluarga tetap berjalan di masa pandemic Covid -19 ini.

Kata Kunci: internet; teknologi; media; pendapatan; ekonomi

\section{PENDAHULUAN}

Indonesia merupakan salah satu Negara yang merupakan mangsa pasar terbesar di Asia. Sehingga masyarakat tidak hentinya mengembangkan dan menciptakan bepulang untuk melakukan kegiatan berbisnis dengan memanfaatkan media social. Penggunaan media social dalam mendukung kegiatan berbisnis adalah informasi dapat menyebar luas kepada konsumen dengan cepat dan mudah. 
Oleh karnanya konsumen dapat dengan mudah memperoleh informasi atau kebutuhan mengenai produk dan pemasaran suatu produk.

Warpindyastuti dan Sulistyawati (2018) menyatakan bahwa Internet dan Teknologi cendrung memiliki dampak positif pada bidang ekonomi dan Bisniss. Seperti telah diketahui masyarakat bahwa Electronis Commerce merupakan kegiatan transaksi bisnis dengan menggunakan internet. Adanya peningkatan yang sangat signifikan pada masyarakat dalam menggunakan E-commerce (Spica, Luciana, Robahi dan Lidia, 2005). Sehingga dalam penggunaannya dapat dikatakan bahwa pelaksana usaha menggunakan E-commerce sebagai basic atau awal penting sebelum melaksanakan bisnis penjuanlan.

Media social merupakan salah satu media yang digunakan pada kegiatan ekonomi digital saat ini. Dengan menggunakan media ini, masyarakat dapat dengan mudah mengembangkan usaha mereka dengan memanfaatkan beberapa sisi positif pada media social. Salah satu sisi positif nya yaitu masyarakat tidak perlu secara langsung datang ke tempat penjualan atau toko dalam melakukan kegiatan pembelian barang yang diinginkan dan secara langsung konsumen dapat meningkatkan efisiensi dalam biaya transportasi untuk mengunjungi toko tersebut. Disisi lain, para pedagang tidak ada keterbatasan promosi walau dengan wilayah atau lokasi toko yang jauh.

Sehubungan dengan pemanfaatan media social dalam kegiatan penjualan, masyarakat secara tidak langsung juga mengembangkan kegiatan Usaha Mikro, Kecil, dan Menengah (UMKM). Dengan adanya kegiatan usaha kecil UMKM tersebut masyarakat juga dapat mengembangkan kegiatan usaha khususnya dengan memperluas lapangan pekerjaan sehingga dapan mendorong masyarakat untuk tetap mestabilkan pendapatan ekonomi rumah tangga dimasa PandemicCovid -19 (Riskiyawan, Azizah, Sasongko, Juniar, dan Ramadan, 2020)

Salah satu strategi dalam mengembangkan suatu usaha adalah kegiatan promosi yang meluas dan tanpa batas apapun (Utami, Sundawa, Pambudi, Murdani, dan Irawan, 020). Selain itu dengan memfokuskan pada kualitas barang yang berkualitas merupakan peranan lainnya. Sehingga dengan adanya latar belakang diatas kegiatan pengabdian kepada masyarakat ini menekankan sosialisasi pada masyarakat di Lorong Kauman Plaju Ulu Palembang dapat tetap melakukan kegiatan jual dan beli dengan memanfaatkan media sosial agar tetap dapat menstabilkan perekonomian dan pendapatan rumah tangga di masa pandemic covid -19 .

Dalam sosialisasi tersebut para pemateri mempersentasikan informasi kepada masyarakat di Lorong Kauman Plaju Ulu Palembang mengenai penggunaan atau pengoperasian penggunaan media social dalam kegiatan jual beli. Sosialisasi tersebut dimulai dari persentasi keunggulan dan kerugian dari media social dalam kegiatan jual beli. Selanjutnya memberikan proses login atau pendaftaran aplikasi media social serta praktik secara langsung pada pendaftarann suatu akun.

\section{METODE}

Kegiatan pengabdian masyarakat ini dirancang dan di lakukan untuk menjelaskan secara detail mengenai informasi, variasi, dan proses pemanfaatan dari media social yang tehubung pada internet dan teknologi. Penelitian ini merupakan penelitian kualitatif atau dengan kata lain pengabdian masyarakat ini memberikan wawasan kepada masyarakat Lorong Kauman Plaju Ulu Palembang tentang berbagai macam manfaat yang dapat menstabilkan serta meningkatan roda perekonomian rumah tangga dimasa pandemic covid -19 . Adapun kalsifikasi dari media social yang sangat dapat 
mendukung kegiatan jual beli atau perdagangan pada Usaha Mikro Kecil Menengah (UMKM) pada masyarakat atau warga disekitar Lorong Kauman Plaju Ulu Palembang.

Adapun tujuan dari pengabdian masyarakat ini adalah untuk menginformasikan kepada masyarakat sekitar lorong Kauman Plaju Ulu Palembang tentang kegiatan usaha kecil menengah yang tetap meraka dapat lakukan dengan memanfaatkan media sosial dimasa pandemic covid -19. Selain itu, dalam penelitian ini menjelaskan dan secara langsung mempraktikkan penggunaan media social yaitu facebook, what's up, instagram, serta sosialisasi mengenai social market dalam kegiatan jual dan beli. Sehingga masyarakat tidak lagi kaku atau kekurangan wawasan dalam memanfaatkan media social dalam kegiatan jual beli atau meningkatkan pendapatan ekonmi rumah tangga.

Pada kegiatan pengabdian masyarakat diselenggarakan dengan memberikan informasi dan tujuan tujuan atas diselenggarakannya kegiatan pengabdian kepada masyarakat kepada pihak mitra atau pada warga masyarakat di Lorong Kauman Plaju Ulu Palembang. Dengan adanya kegiatan ini, peneliti berharap untuk kedepannya pihak mitra dapat lebih mengoptimalkan penggunaan internet dengan memanfaatkan perangkat teknologi komunikasi pada kegiatan atau usaha jual beli. Sehingga dengan tujuan yang sangat umum dari pemanfaatkan teknologi internet dalam kegiatan usaha yang dilakukan dapat meningkatkan produksi penjualan yang meningkat sehingga keuntungan dari penjualan tersebut tetap dapat membuat pendapatan warga di Lorong Kauman Plaju Ulu Palembang tetap optimal di masa pandemic covid -19 .

Dalam kegiatan pengabdian masyarakat ini dilakukan secara tatap muka dengan tetap memperhatikan protocol kesehatan. Kegiatan dilaksanakan dengan mengumpulkan pihak mitra untuk hadir ke masjid Kauman di Lorong Plaju Ulu Palembang. Dalam pertemuan tersebut peneliti dan tim menjelaskan mengenai tujuan serta setiap alur yang akan dilakukan dalam pelaksanaan kegiatan pengabdian kepada masyarakat.

Pada kegiatan pengabdian masyarakat ini diharapkan memberikan kontribuasi yang positif untuk kemajuan ilmu pengetahuan di bidang pengabdian kepada masyarakat secara baik lisan maupun tertulis. Pendekatan yang intens pada masyarakat merupakan salah satu rekomendasi cara untuk dapat megetahui lebih jelas apa sajakah dan bagaimana cara meningkatkan pendapatan perekonomian rumah tangga warga di Lorong Kauman Plaju Ulu Palembang dengan semaksimal mungkin mengaplikasikan teknologi internet pada variasi media sosial yang sesuai tujuannya masing-masing.

\section{HASIL DAN PEMBAHASAN}

Selama pelaksanan pengabdian masyarakat berlangsung, para pemateri memaparkan berbagai informasi yang berkaitan dengan internet, komunikasi dan teknologi yang berkaitan dengan pengoptimalan roda bisnis di masa pandemic. Selain itu materi yang diberikan merupakan materi yang mengerucut pada kaitannya dengan kegiatan berbisnis yang difasilitasi oleh media sosial secara online. Beberapa materi yang dipersentasikan diantaranya: 1) Dampak perubahan social dan ekonomi dimasa pandemi; 2) Pemanfaatan Media Sosial sebagai media pendukung kegiatan bisnis; 3) Sosialisasi aplikasi E-commerce sebagai media kegiatan jual beli secara online. Berikut ini adalah dokumentasi pada saat pengabdian masyarakat berlangsung. 

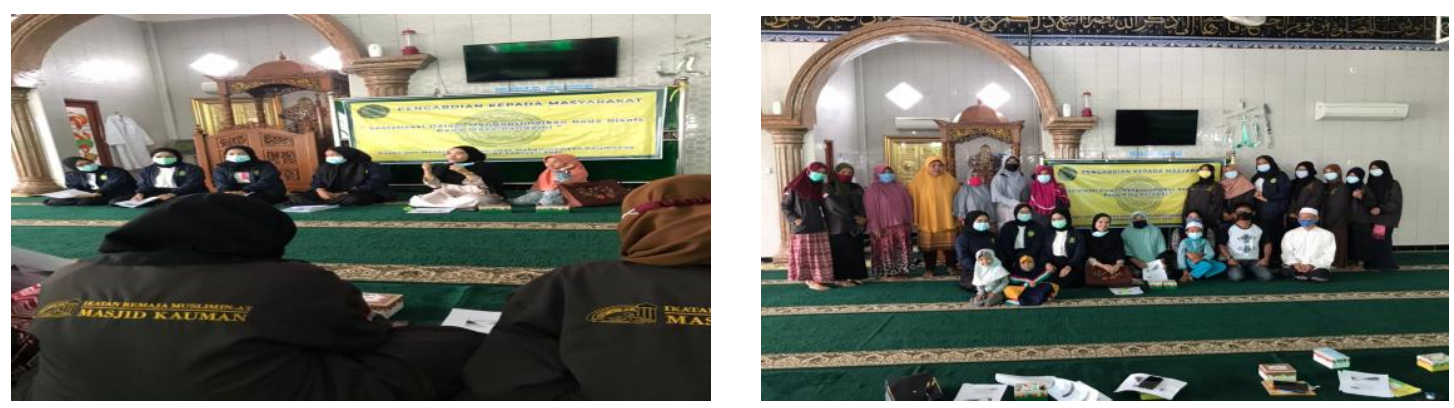

Gambar 1 Sosialisasi Kegiatan E-commerce Berbasis Internet dan Teknologi

Masing-masing pemateri memiliki bagian tersendiri dalam menyampaikan informasi yang baerkaitan dengan judul" Sosialisasi Dalam Mengoptimalkan Roda Bisnis Pada Masa Pandemi”. Materi persentasi dalam bentuk hard copy didistribusikan pada seluruh peserta pengabdian masyarakat yang hadir dengan harapan peserta pengabdian masyarakat dapat dengan mudah memahami informasi yang diberika oleh pemateri. Selain itu materi hard copy yang secara terstruktur mengenai penggunaan sosial media diberikan pada saat pengabdian pada masyarakat dengan harapan dapat memberikan kemudahan untuk para peserta dalam praktik penggunaan lanjtan di rumah masing-masing peserta.

Pada pemaparan materi yang pertama, pemateri menjelaskan mengenai apa saja dampak perubahan yang terjadi di Indonesia karena Pandemic Covid -19. Dampak perubahan meliputi di bidang pendidikan serta perekonomian. Pemateri pertama menggambarkan begitu banyak kalangan bisnis dari menegah kebawah sampai ke menengah atas mengalami perubahan penurunan pendapatan. Sehingga pemateri pertama membuka wawasan para peserta untuk jangan pasrah pada penurunan pendapatan ekonomi dimasa Pandemi Covid -19. Selanjutnya pemateri kedua juga menambahkan informasi mengenai begitu banyaknya manfaat dari Internet dan Teknologi dalam bidang usaha dan bisnis khususnya di masa Pandemi Covid -19. Pemateri kedua juga mengajak para peserta untuk mengungkapkan apa saja kendala yang dihadapi sehingga mereka enggan memanfaatkan fasilitas dari Internet dan Teknologi pada zaman Global seperti ini. Pada akhirnya pemateri ke tiga juga menambahkan mengenai contoh dari E-commerce yang sangat familiar di Wilayah Indonesia. Pembiacara ketiga memberikan latihan secara langsung dalam penggunaan sosial market seperti aplikasi shopee, lazada, blibli. Latihan dimulai dari pendftaran atau tahap login untuk masing-masing aplikasi tersebut. Selanjutnya pembicara memberikan masing-masing fungsi yang terdapat pada setiap icon di aplikasi E-commerce. Pada akhirnya pemateri juga menyimpulkan hal terpenting dari kesuksesan suatu bisnis online adalah dengan mengoptimalkan batasan wilayah.

Pada pelaksanaanya para peserta diminta secara langsung mengaplikasikan informasi yang telah diberikan oleh para pemateri. Selama melaksanakan kegiatan praktik secara langsung dapat di nyatakan bahwa para peserta sangat antusias. Hal ini dapat juga dilihat bahwa banyaknya para peserta melakukan interaksi dengan pemateri dengan memberika variasi pertanyaan yang berhubungan dengan topic kegiatan pengabdian masyarakat. Gambaran antusias atau semangat para peserta juga dapat dilihat dari keadaan diskusi yang sangat interaktif dalam berbagi pengalaman antar peserta yang juga telah memiliki pengalaman menggunakan social media. Sesuai yang telah dinyatakan oleh Reigeluth (1983) bahwa kegiatan pembelajaran atau memahami suatu ilmu yang baru sangatlah membutuhkan suatu praktik secara langsung.

Selain itu adanya diskusi yang sangat antusias antara para peserta untuk menentukan bentuk produk dan jasa apa yang mereka dapat jual belikan. Beberapa kesimpulan bentuk produk dan jasa 
yang akan di promosikan oleh para peserta yaitu; tanaman hias, makanan tradisional, dan bahan makanan atau sembako. Hal itu mereka simpulkan karena barang atau produk tersebut sangat memiliki peluang untuk dapat laris di kalangan pasar wilayah sekitar.

\section{Kesimpulan}

\section{KESIMPULAN DAN SARAN}

Mitra dalam kegiatan pengabdian masyarakat merupakan sekelompok warga dari Kelurahan Plaju Ulu di Palembang. Kegiatan ini dilaksanakan untuk memberikan pemahaman kepada para peserta cara yang dapat dilakukan dalam mendukung peluang bisnis di masa Pandemi Covid 19. Dari kegiatan yang dilakukan sebagian peserta merasakan manfaat dan ketertarikan yang lebih terhadap materi yang disampaikan. Hasil penilaian yang diperoleh menunjukkan bahwa dari sisi kepuasan peserta terhadap pelaksanaan kegiatan sangat baik.

\section{Saran}

Kegiatan pengabdian kepada masyarakat ini diharapkan dapat memberikan saran pada para pembaca dan tim pengabdian pada masyarakat untuk selanjutnya agar adanya kerjasama yang baik dan kompak antara mitra dan pemakalah sehingga dapat tercapai tujuan kegiatan pengabdian pada masyarakat dengan optimal.

\section{DAFTAR PUSTAKA}

Alrivando, D., Elmanda, N., Wahyuningtyas, D. Utami, P., Alviantoro, I., Rifki, A., Munafehi, N. (2020). Pemanfaatan Media Sosial Sebagai Strategi Pemasaran dalam Menunjang Peluang Usaha Mandiri di Masa Pandemi Covid -19. Universitas Negeri Semarang. Semarang.

Reigeluth, Charles M. (ed). 1983. Instructional Design, Theories and Models: An Overview of Their Current Status. New Jersey: Lawrence Erlbaum Associates Publishers

Riskiyawan, A., Azizah, N., Sasongko, A., Juniar, A., Ramadani, S. (2020). Strategi Pengembangan Usaha Mikro, Kecil, Menengah Kerajinan Tangan "Ardila Art” dengan Pendekatan Pentahelix dan Analisis SWOT di Desa Panusupan, Kabupaten Purbalingga. Universitas Negeri Semarang. Semarang.

Spica, Luciana dan Robahi, Lidia. (2005). Penerapan E-Commerce sebagai upaya meningkatkan persaingan bisnis perusahaan. STIE Perbanas Surabaya.

Utami, P., Sundawa, A., Pambudi, A., Murdani, A., Irawan, A. (2020). Strategi Pengembangan Produk Unggulan UMKM Tas Rajut “Asbag” di Kelurahan Karanganyar Gunung Kota Semarang. Jurnal Pengabdian Masyarakat ABDIMAS.

Warpindyastuti, L. D., \& Sulistyawati, M. E. (2018). Pemanfaatan Teknologi Internet Menggunakan Media Sosial Sebagai Sarana Penyebaran Informasi dan Promosi pada MIN 18 Jakarta. Jurnal Widya Cipta. Vol. 2(1). 